\section{Russians at} conferences

SIR,-..."Have the Russians arrived?" International conference-goers will know how the question passes from one to another as they assemble at the start of the meeting. The uncertainty of whether the Soviet delegation will appear or not (and if they appear, on which day?) has long provided a touch of drama for the other participants and a headache for the organisers. The first clue for the organisers is often a message from the travel agency acting for Intourist that they are asked to book hotel accommodation for so many Soviet delegates. The names may not be known, only the total number, and the scientific contact with them will commonly not be direct but through some official Soviet committee or authority.

I have recently returned from an international conference abroad where this scenario was duly re-enacted, but this time I experienced it directly as I had to preside over the meeting. Writing now in my private capacity, not as president, I have to report sadly that nothing has changed; it is as bad as ever.

We had asked a prominent Soviet scientist, let us call him Professor $\mathbf{Y}$, to give one of the specially invited review papers and our invitation was accepted. As the time drew near the secretary of the meeting wrote to him several times to ask about his paper, but with no reply. Telegrams were tried, and then many telephone calls to Moscow. Professor $Y$ was unknown to them, they said; or, Professor $Y$ had gone away. Faced with this concerted silence, we began to fear for our colleague. Finally, four days before the opening of the conference we received a telegram from Professor $\mathrm{Y}$ that his paper would be presented on arrival. (All the other papers for the conference had already been reproduced for distribution.) Our hopes rose, but we remembered the old Russian proverb "Do not sell the bearskin until you have shot the bear." The Soviet delegation, expected to be twelve, turned out to number seventeen, including the usual chaperone from Intourist, and Professor $\mathrm{Y}$ was not among them. They bore with them copies of his paper for distribution and a verbal message from him asking me to present it. I did so, believing that my colleague was in no way to blame for these bizarre events and wishing to help him in his difficul- ties as much as I could (the rules of the conference just allowed it). It is worth adding that some or all of the five extras in the Soviet party did not have enough foreign currency to pay the fee and so were unable to be registered for the conference.

The Soviet authorities who are responsible for these things should realise that this sort of behaviour on their part is harmful to Soviet science. Organisers of conferences already think twice before inviting papers from Soviet authors, knowing the uncertainties that will result. We should like to include them, on equal terms with the others, but how can we go on doing so in face of this continued official discourtesy to the scientific community? Yours faithfully,

J. D. NYE

H. H. Wills Physics Laboratory,

University of Bristol, $U K$

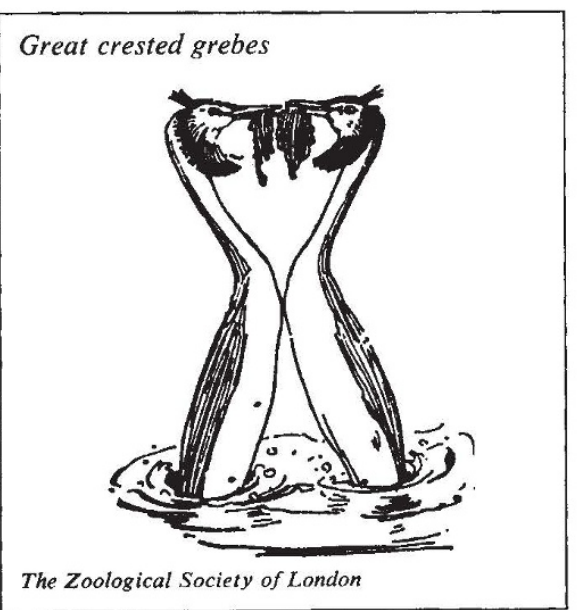

\section{Darwin's omission}

SIR,-I wish to draw the attention of historians of science to the omission by Darwin (in his Origin of Species and even in his Selection in Relation to Sex) of any mention of cases where the two sexes are similar in plumage. Sexual selection for Darwin involved the choice by females of brighter, and often larger, males. Darwin presumably did not have the opportunity to study sexually similar species: once be returned to Down House he was not able to observe freshwater or marine birds.

The same omission occurs in the books on evolution by Ernst Mayr, in Bernard Rensch's Evolution above the Species Level and, strangely enough, in the early edition of my own Evolution, the Modern Synthesis. I say strangely, for in the years 1914 to 1917 , I myself had described the elaborate mutual display of grebes, herons and egrets; and later returned to the display of swans, albatrosses, and penguins, which had been studied in detail by others. The first account of mutual display was given by E. Selous in 1901-02, and by myself in 1914; in both cases, of great crested grebes (Podiceps cristatus, Proc. zool. Soc. Lond., 1914). My failure to mention mutual display in my book seems to have been due to my not realising its frequency or its biological value in strengthening the emotional bond between members of a pair. This point emerges clearly from the work of Lorenz and Tinbergen.

I wish to stress the strikingly different results of unilateral and mutual display, in regard both to display characters and to behaviour. A regular feature of mutual display is that the returning bird presents the sitting mate with nest material (in grebes a similar presentation occurs on open water). Another feature of mutual courtship is the extent of ritualisation; but this also applies to many male unilateral displays where the sexes have different plumage, as in bustards, pheasants, some grouse, and so on. Today the importance of ritualisation has been confirmed: see the Royal Society's symposium on Animals and Man (Phil. Trans. R. Soc., 1966).

The red breast in both sexes of the robin (Erithacus rubecula) is not connected with courtship: Lack has shown that the colour is a mark of territorial ownership, for both sexes have winter territories. In dimorphic species the songs of males, and of 'duetting' birds such as some African Shrike, are also proclamations of territory.

Yours faithfully,

Julian Huxley

31 Pond Street,

London NW3, UK

\section{Rat race}

SIR, - a recent advertisement emphasises the present crisis in biology laboratories, where research is severly hampered by the shortage of experimental animals. "A position of Wissenschaftlicher Rat is vacant" in Freiburg (Nature, March 1, xx; 1974); applicants should have experience of cell-mediated immune reactions.

Yours faithfully,

Hove, UK
B. Jove 